\title{
O cinema silencioso e o som no Brasil (1894-1920) ${ }^{1}$
}

\author{
Danielle Crepaldi Carvalho
}

Resumo: O cinema silencioso recorreu ao som desde o princípio. Porém, malgrado a relevância da conexão dessas duas esferas, apenas recentemente estudiosos estrangeiros se debruçaram sobre os usos que o cinema silencioso fez do som. No Brasil, pesquisas neste âmbito ainda tateiam. Este artigo pretende recuperar os usos que o cinema silencioso fez do som em território nacional, das primeiras experiências com o kinetoscópio (em fins de 1894) até o início de 1920, momento da estabilização do lugar da música no espetáculo cinematográfico. Partindo de uma perspectiva transdisciplinar, pretende-se demonstrar que a cena cinematográfica desse período integrava um contexto de circularidade cultural: apropriava-se de canções populares e eruditas queridas do público e, ao costurá-las aos filmes silenciosos, os impregnava dos sentidos já construídos - elaborando, por conseguinte, sentidos outros, aos quais se misturavam as sombras moventes dos artistas das telas à polifonia social.

Palavras-Chave: cinema silencioso; história do cinema brasileiro; som e cinema.

Abstract: Silent movies and the sound in Brazil (1894-1920) - The silent cinema has recurred to sound from its beginnings. Despite the importance of the connection between these two spheres, only recently foreign scholars began to study the uses the cinema made of sound. Here in Brazil, researches of this field are only beginning. This essay aims to recuperate the uses the silent movies made of sound in national ground, from the first experiences with the kinetoscope (in the ends of 1894) to the beginning of the 1920s, when the place of the music in the cinematographic spectacle was stabilized. From a transdisciplinary perspective, we intend to prove that the cinematographic scene from this period integrated a context of cultural circulation: when popular music and songs were used as accompaniment for the silent films; impregnating the cinematograph with former meanings, as well as constructing new meanings - ones that mixed the moving shadows of the artists to the social polyphony.

Keywords: silent movies; Brazilian's cinema history; sound and cinema.

1 Uma versão deste trabalho foi apresentada no GT "Comunicação e Cultura", da COMPÓS de 2016. Agradeço os apontamentos dos colegas do evento e em especial de meu supervisor de pesquisa, Prof. Eduardo Morettin, visando ao aprimoramento do texto. 


\section{O sonoro cinema silencioso}

A voga do cinema dito silencioso deu-se entre a invenção da arte - 1895 - e a rodagem de The Jazz Singer, em 1927. Tal assertiva, vulgarizada pela historiografia do cinema e aceita para fins práticos, está passando por revisão nos últimos anos. ${ }^{2} \mathrm{O}$ som foi parte integrante do primeiro cinema, recuando-se a afinidade entre o som (a música, em especial) e as imagens, segundo Giusy Pisano (2002, p. 2, tradução nossa), à "história ancestral dos espetáculos luminosos". Quatro anos antes da histórica apresentação cinematográfica dos irmãos Lumière em Paris, os jornais brasileiros já noticiavam o tour de force do inventor norte-americano Thomas Edison no sentido de unir os mecanismos reprodutores da imagem e do som: "Este instrumento permite a uma pessoa, sentada em seu gabinete de estudo, ouvir a voz dos cantores ou dos atores e a música de uma peça e ver, ao mesmo tempo, reproduzida em um cilindro, toda a cena do teatro, as figuras e os gestos dos atores." (NOTAS DIVERSAS, 1891, p. 1).

A primeva descrição do kinetophone ${ }^{3}$ acima citada (a nota publicada na imprensa carioca data de 1891, enquanto que tal aparato apenas começou a ser comercializado em 1895) atesta que o novo espetáculo era vocacionado ao ruído, não ao silêncio. O sonho com o "cinema falado" data de antes do advento do cinematógrafo. Antes de o kinetoscópio de Edison aportar no Brasil, já os jornais cariocas anunciavam o esforço do inventor no intuito tanto de projetar as figuras diminutas "por meio da lanterna mágica", quanto de "combinar o fonógrafo com o kinetoscópio, de modo que as figuras falem e se movam ao mesmo tempo." (O KINETOSCÓPIO, 1894, p. 1).

A questão é a tônica do artigo de Tom Gunning (2001, p. 16. Tradução nossa), publicado no incontornável The Sounds of Early Cinema: o fonógrafo, segundo ele, havia tornado possível a separação dos sentidos humanos perscrutada pela ciência do século XIX, "divorciando-se o ouvido dos olhos" . A realização de tal projeto originara, no entanto, ansiedade: as vozes incorpóreas atrelavam-se ao âmbito do sobre-humano; dos demônios e dos espíritos. Ao investir em pesquisas relacionadas à fotografia em movimento, segundo Gunning, Edison estaria buscando reunificar os sentidos que o seu invento desconectara.

O objetivo final da empreitada era, segundo o ensaísta, "a preservação da personalidade humana sobre a morte"; o triunfo sobre a finitude por meio de um duplo mecânico (ibidem, p. 27. Tradução nossa). A produção literária de fins do XIX mimetiza o ensejo: Gunning utiliza como exemplo uma novela de Julio Verne anterior ao cinematógrafo, The Carpathian Castle (1892), na qual a prima-dona morta apresentava-se rediviva aos seus dois apaixonados graças à conexão de um dispositivo reprodutor de

2 Costa (2008) compila o conjunto de pesquisas brasileiras voltadas ao som no cinema, ratificando a raridade com que a questão é tomada como objeto de estudo. Para um balanço resumido do contexto estrangeiro, conferir, sobretudo, a "Introduction" de ABEL; ALTMAN, 2001, p. xi-xv.

3 Denominado erroneamente "kinetógrafo" pelo autor da nota (o kinetograph era a câmera usada no registro das imagens kinetoscópicas). 
imagens - construído por meio de um conjunto de vidros, à maneira das fantasmagorias - e de um sucedâneo do fonógrafo. Os exemplos desta literatura, em que os voos da fantasia procuram, ao fim e ao cabo, explicarem-se por meio do realismo, são inúmeros, e este artigo não tem como intuito elencá-los. Ao abordar a narrativa de Verne, Gunning (2001, p. 28) visa se filiar às ponderações de André Bazin sobre o "cinema total": desde o princípio, o cinema teve por objetivo capturar os mais variados aspectos do mundo sensual: o conjunto de suas cores, dimensões e sons.

No que toca aos sons, consideremos a relação incontornável da música, especificamente, com a sociedade fin de siècle. A música estava inextricavelmente ligada à cena teatral - meio ao qual o cinematógrafo recorreu para formar seu corpo cênico e os enredos das curtas vistas -, sendo parte fundamental de uma variedade de gêneros cômicos e dramáticos de cunho espetacular em ascensão no século XIX, como o vaudeville, a opereta, os espetáculos funambulescos, a mágica e o melodrama; espetáculos nos quais se entremeavam cenas pungentes e digestivos números musicais (cf., por exemplo, ALTMAN, 2004; THOMASSEAU, 2009; CARVALHO, 2014). E tal âmbito espetacular encontra natural continuador no cinema de atrações, com o qual dividiu mesmo o espaço físico de suas salas, nos primeiros anos da nova arte.

Para se ter uma ideia, Viagem à lua (1902), de Georges Méliès, foi apresentado no Rio de Janeiro pela primeira vez em 1903, no teatro S. Pedro de Alcântara e no teatro do Parque Fluminense; no primeiro, durante o espetáculo da "Companhia Imperial Japonesa Kudara", entre números de funambulismo e a exibição das fotografias coloridas do "bioscópio de Ferragut", e, no segundo, em seguida ao ensaio geral da ópera de Pietro Mascagni Cavalleria Rusticana (de 1890). Um ano mais tarde, quem recebeu a fita foi o Teatro Lírico, desta vez como espetáculo solo, no contexto do "Cinema Falante" da empresa E. Hervet (PALCOS E SALAS, 1903, p. 3; TEATROS E..., 1903, p. 2; TEATRO LÍRICO, 1904, p. 6).

Raras são as informações sobre os usos do som, nestes primeiros dez anos de cinematografia. Sabemos um pouco mais sobre os espetáculos da Cia Hervet, cujos anúncios informavam claramente quais eram as fitas "falantes". A mesma companhia indica a apresentação de ouvertures musicais, a abrirem cada uma das partes da programação. No mais, pouco se sabe. Parece impossível, no entanto, que a buliçosa cena teatral da virada do século XIX para o XX tivesse recebido silenciosamente o cinema silencioso. Em especial a cena carioca, onde atuavam dezenas de bandas e grupos de amadores de música. Vulgarizado entre nós o fonógrafo, as modalidades de escuta da música apenas fizeram aumentar - registros jornalísticos e literários dão conta da venda e circulação de vozes e ritmos procedentes das mais diversas partes do mundo, desde os primeiros anos do século XX (Cf. GIL, 1909). Uma vez tendo entrado na dinâmica da cena ágil e festiva de então, o cinematógrafo apropriou-se dos mecanismos que a faziam tão querida do público. 


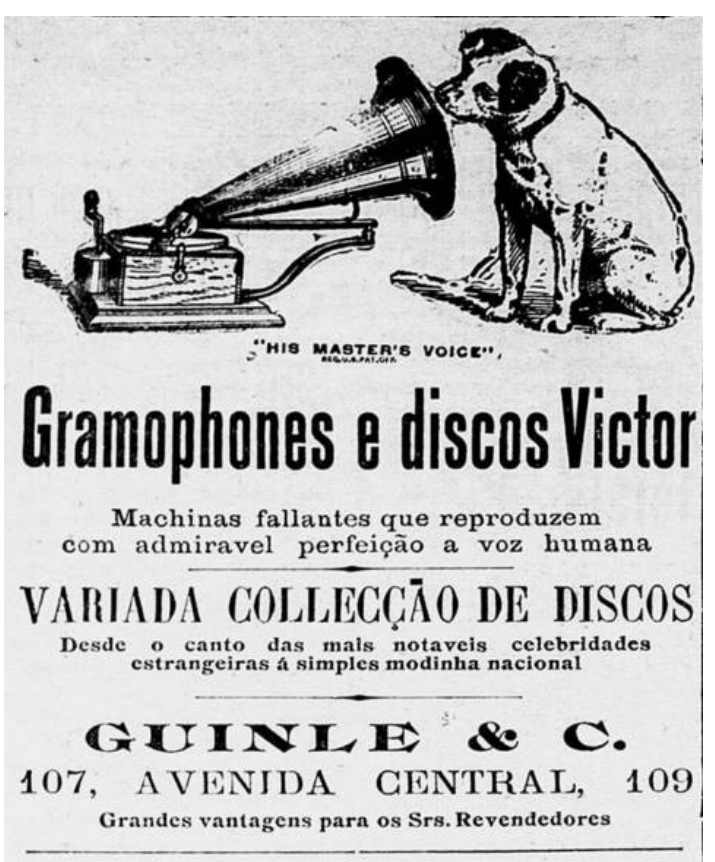

Fig. 1. Anúncio dos Gramofones e discos Victor

Fonte: Gramofones, 1911, p. 8. Biblioteca Nacional Digital: <memoria.bn.br>

Considerando-se a sua histórica preocupação com a conservação e a sistematização das fontes primárias, a Europa é mais pródiga que o Brasil em informações acerca do tema. Pesquisas desenvolvidas nos últimos anos debruçam-se desde nos usos empíricos do som no cinema até nos fatores psicológicos a ele inerentes. Pianos ou fonógrafos - a depender das condições financeiras da sala - acompanhavam, na França, as primeiras exibições cinematográficas do século, afirma Giusy Pisano (2002). Já espaços maiores, como a sala de atrações dos "Grands Magazins Dufayel", contavam com orquestra, piano e um gramofone com uma vasta gama de discos, a trabalharem alternadamente. Com o tempo, o acompanhamento musical se sofisticou. Empresas produtoras de filmes passaram a oferecer decupagens musicais às fitas que rodavam, ou a indicar os trechos que melhor acompanhassem cada cena; criaram-se catálogos de partituras ou de gravações. A busca por maior sincronismo entre música e som deu ensejo, na Europa do início dos anos de 1920, à preparação de manuais, distribuídos ao redor do mundo - esforço visando à uniformização do métier.

Ainda segundo Pisano (ibidem), provas do crescente rebuscamento no que toca à participação da música no espetáculo cinematográfico são os arquivos de salas francesas importantes nos anos de 1910 e 1920, como a "Gaumont-Palace" e a já mencionada "Dufayel". Por meio dessas fontes, sabe-se que a escrita de partituras específicas para 
os filmes era rara. Buscava-se, ao contrário, acomodar à ação músicas já conhecidas do público - oriundas de poemas sinfônicos, da música de concerto e da ópera -, que evocassem no espectador um efeito já esperado (Ibidem, p. 5-6). Escolhia-se, ademais, um repertório alinhado aos gostos do momento, o mesmo que era reproduzido em cafés, halls de hotel e cassinos (Ibidem, p. 5-6).

Quanto o cinema não deveu, para a sua popularização, à utilização de músicas já pertencentes ao imaginário do público? Quantos seres feitos de sombras não tiveram seus destinos tecidos pelas almas de célebres personagens da cena operística de então? Guido Bagier refere-se aos inúmeros beijos "à americana" embalados pelo tema da Morte de Isolda (ibidem). Os passionais heróis norte-americanos ganharam, assim, carnadura nórdica ${ }^{4}$. Enquanto que, no Rio de Janeiro, a música ocidental tornava mais e mais palatável a "bizarria" dos habitantes do Oriente, e logo o "Cinematógrafo Japonês" da Avenida Central, aberto em setembro de 1908, já motivava, na haute gomme carioca, a incorporação de um modus vivendi pseudo-oriental. A música e o cinema da virada de século compartiam do contexto de uma incipiente indústria cultural, que embaralhava povos e culturas; transformando-os em itens de consumo das massas e redefinindo as sensibilidades.

Se o cinema não foi o primeiro espetáculo que fez uso da música para a sua efetivação, ele se apropriou intensamente dela. Fosse no intuito de sublinhar a tensão da cena e titilar a atenção do público, reforçando o contexto emotivo da ação. Fosse para abafar o ruído alheador dos primeiros projetores - aos quais a crítica brasileira pouco amigavelmente denominava maquininhas de moer. Fosse para destacar o espaço diegético da ação dos incontroláveis ruídos do ambiente externo. Fosse para mimetizar, na sala de exibição, a polifonia do mundo exterior. Fosse, ainda, para remover as cinzentas sombras do cinema do éthos de fantasmagoria ao qual elas estavam incontornavelmente atreladas (Cf. PISANO, 2002), inserindo-as na fluidez melodiosa e harmônica da música - que convidava aos bailados, à alegria dos gêneros alegres, às belezas dos quadros operísticos.

\section{O caso brasileiro}

Retornemos ao Rio de Janeiro de agosto de 1903, à Viagem à lua apresentada entre os funâmbulos japoneses e os brinquedos do Parque Fluminense. Que música teria embalado os quadros de Méliès? A contar pelos jornais, a Cia Kudara trouxe à cidade, além do cinematógrafo e do bioscópio, equilibristas, cães amestrados e um malabarista que realizava a proeza de acionar, com os piões que manejava, a traquitana que tocava o Hino Nacional brasileiro. No Parque, a exibição da fita seguiu-se aos ensaios da popularíssima Cavalleria Rusticana - hino passional às camadas populares italianas. Infere-se, portanto, que a fantasia francesa recebeu, senão o acompanhamento, ao menos os eflúvios de

4 Edgar Morin destaca a inclinação do cinema ocidental ao uso da música romântica; tentativa de se construir uma "civilização romântica da alma", que é próxima do cinema burguês. Cf. MORIN, 1970, p. 168-169. 
temas de naturezas variadas, que pouca identidade direta possuíam consigo, mas que, ao serem apresentadas na ocasião, acrescentavam aos seus sentidos; prova da fusão cultural que então ocorria.

Este breve apontamento sobre o contexto nacional faz emergir a variedade de usos do som no Brasil dos tempos de cinema silencioso. Apenas o trabalho de Jean-Claude Bernardet (1979), da produção brasileira exibida na cidade de São Paulo nas primeiras décadas do século, já amplia o escopo para dimensões consideráveis. Por meio dele, descobrimos, por exemplo, que o ano de 1909 foi pródigo para a empresa Serrador, cujas "fitas cantantes" foram exibidas no Cinema Bijou, com cantores a reproduzirem, ao vivo, o repertório dos teatros cariocas (quiçá também paulistanos) ou as canções populares na cidade, nacionais ou estrangeiras: cançonetas, canções de carnaval, números musicais de zarzuelas e operetas, árias de óperas ${ }^{5}$. Exemplares de produções populares e eruditas dividiam espaço nos gostos do público. João do Rio, por meio do pseudônimo Joe (1907, p. 1), diria: "O carioca é variável como o tempo, a questão era descobrir seu barômetro, porque, além do maxixe e vissi d'arte [notória ária da Tosca] não há nada neste país que tenha resistido a cinco anos de vida".

A produção musical erudita, que durante todo o século XIX penetrou nas mais diversas classes sociais - tanto pela frequência in loco dos teatros como pela venda das partituras das óperas, reduzidas às suas mais célebres árias, reproduzidas das casas das famílias abastadas aos clubes dos arrabaldes - via-se exponencialmente disseminada depois do advento do fonógrafo. Por meio da maquininha "implacável", a "vítima" podia ouvir à farta, no seio familiar, ora "a 'Tosca' por Caruzzo (sic.)", ora "um delicioso trecho do abade Perosi", compositor italiano de música sacra (Cf. GIL, 1909; REDONDO, 1912, p. 25-36).

A mise-en-scène das fitas ${ }^{5}$ de reprodução e de presença empírica, de cinema a ainda resvalar para teatro, não deve ser perdida de vista, pois corresponde a um momento privilegiado deste entrecruzamento entre cinema, teatro e música.

Que fatores determinaram tal idiossincrasia? A opção não se deu por deficiência técnica, uma vez que, desde ao menos 1904, o Teatro Lírico recebia a visita do "Cinematógrafo Falante", propriedade da empresa E. Hervet. A contar pelos anúncios publicados nas folhas cariocas da época, durante os verões de 1904, 1905 e 1907 as companhias operísticas cediam o Lírico às fitas, a uma orquestra - sabe-se que o programa se iniciava por uma ouverture orquestral; não se sabe, no entanto, detalhes referentes ao acompanhamento musical dessas fitas - e ao "Cinematógrafo Falante", ponto alto do espetáculo. Algumas dessas fitas: Bonsoir, Mme. la Lune (1904); La femme est un jouet (1904); Serenade de Pierrot (TEATRO LÍRICO, 1904, p. 6; OPINIÃO DA IMPRENSA, 1905; A. A., 1907, p. 1). Acerca da última, o Jornal do Brasil tece o comentário a seguir, fundamental para que se compreenda a encenação do espetáculo e a reação do público:

5 A respeito dos filmes cantantes que reproduziam canções populares, Pereira (2014, p. 18) cita Pega na chaleira, alusiva à polca homônima, sucesso no carnaval de 1909 . 
Ouvimos e vimos então a linda romanza Serenade de Pierrot, cantada por Monsieur Mercadier. É perfeitamente harmônica a marcha dos dois aparelhos de sorte que se casa a voz com o gesto, com o mover de lábios, de tal sorte que o público entusiasmado aplaudiu o cantor, e o notável é que este voltou à cena - ao pano branco - a agradecer com sorriso. O público exigiu bis, mas o cantor já estava enrolado e foi preciso desenrolá-lo e dar corda nova na sua voz o fonógrafo - para que houvesse bis. A ilusão é completa e produz um efeito encantador. (PALCOS E SALÕES, 1904, p. 2).

O número protagonizado por M. Mercadier lembra a mise-en-scène que depois seria empregada nas phonoscènes da Gaumont: o cantor, que era tomado em plano mais aberto ou fechado, apresentava todo o ato numa única tomada, após o que saía de cena, retornando para receber os aplausos da plateia hipotética. Não só a mise-en-scène do número é tributária do teatro, como também a repetição do espetáculo aplaudido. A mistura sui generis não deixa de originar, no entanto, uma "ilusão" de realidade análoga à que apontara Gunning (2001) ao discorrer sobre a narrativa de Verne. O fato leva o articulista do Jornal do Brasil a produzir a nota risonha, na qual assinala quão inusitado era desenrolar-se o cantor impresso em película para que ele respondesse aos afagos de um público objetivamente presente na sala.

Tais prodígios técnicos não foram aceitos entre nós de maneira unívoca. A última referência ao "Cinematógrafo Falante" de E. Hervet encontrada data, como dissemos, do fim de 1907. Em setembro de 1908, a Fon-Fon faz menção ao "Sincronoscópio Lírico", sublinhando, na mesma ocasião, que as fitas cantantes - dentre elas estava uma ária da ópera Amica, de Mascagni - não teriam agradado o público (SINCRONOSCÓPIO LÍRICO, 1908). Meses antes, a ocasião da Semana Santa motivou, no Rio de Janeiro, a exibição de quadros cinematográficos de Cristo acompanhados in loco de "música sacra, incenso, coros e vozes femininas" ${ }^{\prime \prime}$. Poderíamos considerar um retrocesso a presença empírica dos cantores, a acompanhar as fitas? Ou, ao contrário, eles faziam multiplicar as potencialidades do invento, dando ao espetáculo cinematográfico ora foros de cerimônia litúrgica, ora de teatro alegre, ora de cena operística?

Com o galgar dos anos, o fonógrafo parecia ser incapaz de criar a "ilusão [...] completa" (PALCOS E SALÕES, 1904, p. 2) de realidade que uma vez produzira. O movimento da estupefação ao desdém é tecido pelo conto de Garcia Redondo denominado "O Fonógrafo", narrativa das peripécias de Julião - sitiante abastado e iletrado de um rincão paulistano -, numa das vezes em que ele decide "vê a capitá". Após ser apresentado ao fonógrafo, se sucedem, no caipira, o maravilhamento inicial, a incredulidade frente às vozes incorpóreas (e a consequente procura pelos cantores que certamente estariam escondidos nas cercanias da máquina...), a adesão (Julião compra

6 A fita em questão, denominada A Tragédia do Calvário, foi apresentada no Cinematógrafo Pathé. Para maiores referências a ela, cf. CARVALHO, 2014, p. 169. Para a referência ao supradito espetáculo da Semana Santa, cf. [PIMENTEL], 1908, p. 2. 
uma caixa para que possa "assombrar depois os povos dos terrenos desconhecidos, onde ele habitava") e, enfim, o repúdio ao "papagaio de metal" que "moía" "o compasso das músicas" (REDONDO, 1912, enquanto que o conto data do princípio do século XX). A precariedade técnica do aparelho havia subitamente se tornado patente. "A agulha risca o disco e uma voz rouquenha e aflautada anuncia: "O angu do Barão", cantado pelo Mario para a casa Figner, Rua do Ouvidor, Rio de Janeiro.", dirá Gil (1909).

Num momento em que o fonógrafo resvalava para o risível $^{7}$, ofereciam-se alternativas ao público. Daí os artistas passarem a ocupar empiricamente o espaço da sala de exibição, concorrendo, com suas vozes reais, à verossimilhança das cenas cinematografadas. Em janeiro de 1909, o carioca Teatro Lírico novamente marcava época. Não apenas por apresentar, com um curto lapso de tempo quando comparado à matriz parisiense, os primeiros films d'art - entre eles L'Assassinat du Duc de Guise (1908, André Calmettes, Charles Le Bargy) com música composta especialmente por Saint-Saëns e executada por uma orquestra cuja formação se assemelhava à daquelas que executavam a programação lírica da cidade -, mas o que se imaginam serem as primeiras fitas vocalizadas por músicos situados atrás da tela: Duo da Africana (Serrador, 1909), por Claudina Montenegro e Santiago Pepe, e o Dueto do Guarani (Serrador, 1909), por Claudina e pelo tenor Santucchi (TEATRO LÍRICO, 1909, p. 6).

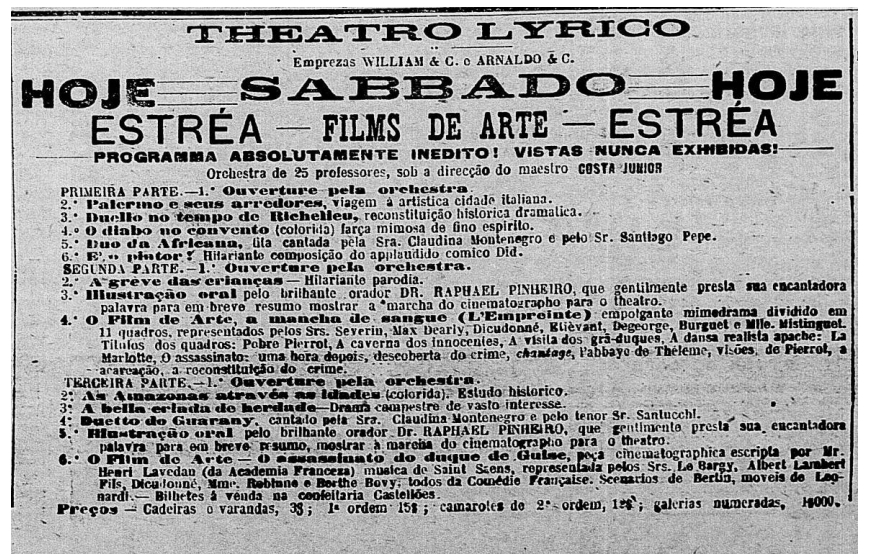

Fig. 2. Anúncio dos Filmes de Arte no Teatro Lírico

Fonte: Teatro Lírico, 1909, p. 6. Biblioteca Nacional Digital: <memoria.bn.br>

A solução, embora não tenha sido acolhida com empolgação unânime por parte do público e da crítica, renderia frutos. Oscar Guanabarino, longevo e influente crítico de arte da imprensa carioca, não poupou ironias aos cantores ou aos músicos, considerando-os aquém da sociedade que os prestigiara no Lírico. Detendo-se na cantora Claudina

7 O Teatro Lucinda chegara a apresentar, no seu espetáculo de variedades, vistas do Cinematógrafo Pathé e a apresentação do cômico Cesar Nunes, "conhecido pelo nome de guerra de fonógrafo humano, por imitar o conhecido aparelho." Cf. TEATROS: LUCINDA, 1907, p. 3. 
Montenegro e no tenor Santucchi, denominou a primeira "artista de zarzuelas", e o segundo, "tenor que se vestiu de espanador para fingir de Peri e cantar o dueto do Guarani, a caráter, com uma Ceci com as vestes de 1900, procronismo ao lado de uma tolice que revela a ignorância do organizador do quadro" (O. G., 1909, p. 3). No que tocava à orquestra, não deixou por menos: "a orquestra incompleta do professor Costa Júnior sacrificou [a partitura de L'assassinat du duc de Guise] com a mesma sem-cerimônia com que meteu os pés pelas mãos no prelúdio do $5^{\circ}$ ato da Traviata" (O. G., 1909, p. 3). Todavia, tal repúdio não impediria esses cantores de passar os próximos anos realizando o ofício.

A programação "cantante" não se restringe a essas obras. Segundo o levantamento de Bernardet, estiveram em São Paulo também os cantores Enzo Banino e Amica Peliser (desempenhando solos e duetos da Bohéme, da Tosca, da Traviata, de I Guarany, I Pagliacci etc.). E apresentaram-se na cidade, além dos curtos números musicais tributários das phonoscènes da Gaumont, as operetas cinematográficas mais extensas: apenas no que tange à Viúva Alegre, foram três as versões (em italiano pela Cia Lahoz, com orquestra do prof. Gonçalves, em agosto de 1909; e em português, pela Cia Rio Branco, em dezembro de 1909, e pela Cia Serrador, em fevereiro de 1910, cf. BERNARDET, 1979 e MORETTIN, 2009). Tais fatos demonstram que o cinematógrafo de então se impregnava das características da cena teatral.

\section{Rastros de uma arte mestiça: Viúvas Alegres e Guaranis entre os livros, os palcos, as ruas e os cinematógrafos brasileiros}

Jean-Claude Bernardet deixa-nos lições importantes em sua Historiografia Clássica do Cinema Brasileiro (1995). O crítico questiona a periodização da história de nosso cinema, proposta por Gomes no Panorama do Cinema Brasileiro (1896-1966) - obra preocupada em destacar os momentos de encontro do cinema brasileiro com seu público -, para propor um mergulho vertical em recortes temporais mais restritos e, a partir daí, um trabalho de cunho interdisciplinar, que considere as relações estabelecidas entre o cinema e a cultura de seu tempo (BERNARDET, 2008. Cf. também MORETTIN, 1997).

Proposta luminosa, se considerarmos que a segmentação do conhecimento em disciplinas obedece a fins puramente práticos. O complexo das relações sociais tece-se por trocas, interpenetrações múltiplas, avanços e recuos que a leitura panorâmica não permite apreender, já que almeja generalizações que sempre soam artificiais. Tomemos como exemplo as Viúvas Alegres cinematográficas. Surgidas num tempo em que o cinema brasileiro - sempre alinhado às inovações vindas d'além mar - poderia dispor de tecnologias como o Chronophone da Gaumont, elas foram apresentadas segundo o método artesanal de se posicionarem os cantores atrás das telas. Influência direta dos palcos, que àquela época recebiam "Viúvas Alegres" das mais diversas nacionalidades. O cronista Raviuli (1909) dá um depoimento tragicômico sobre a invasão dessas sedutoras senhoras, nos mais variados 
idiomas, dos teatros do Rio de Janeiro ${ }^{8}$ aos pianos das salas de espera dos cinematógrafos, às bandas de rua, aos bares, ao piano da casa da família, enfim...

O espraiar-se da "Viúva Alegre" pela cidade, em gêneros e línguas variadas, em versões completas ou por meio de suas árias mais queridas, patenteia a complexidade da circulação cultural naquele início de século. O coração da cidade batia no compasso das célebres "Viúvas...". A "intensidade vibrante da (...) música quente e afrodisíaca" (FLÁVIO, 1909) da opereta ajudava a capital do país a se despir dos seus costumes arcaicos. Nas salas de cinema, as versões das Viúvas que corriam pelo pano branco impregnavam-se da polifonia da cidade; os sentidos dos filmes construindo-se do rescaldo desses objetos vários, e acrescentando depois, a eles, sua porção de sombra e de sonho.

Um último exemplo que ilustra a importância de se pensar no cinema em diálogo com o complexo contexto sócio-cultural no qual ele se inscreve: as informações arroladas até aqui demonstram que a nossa produção cinematográfica nutriu um verdadeiro fascínio pelo Guarani. Além do histórico Dueto do Guarani, marco inicial dos filmes cantantes nacionais, apresentado no Rio durante a exibição dos "Filmes de Arte", e depois em São Paulo, houve Os aventureiros (Serrador, 1909), ária daquela ópera cantada por Pepe (em S. Paulo, a 2 set. 1909). Ademais, várias versões cinematográficas completas da história de Peri e Ceci foram exibidas a partir de 1908, data da rodagem de Os Guaranis, protagonizada pelo palhaço negro Benjamin, do Circo Spinelli, fita, por sua vez, oriunda da pantomima encenada meses antes por ele (Cf. BERNARDET, 2008; MORETTIN, 1997, p. 263-266; CINEMA PALACE, 1908, p. 10).

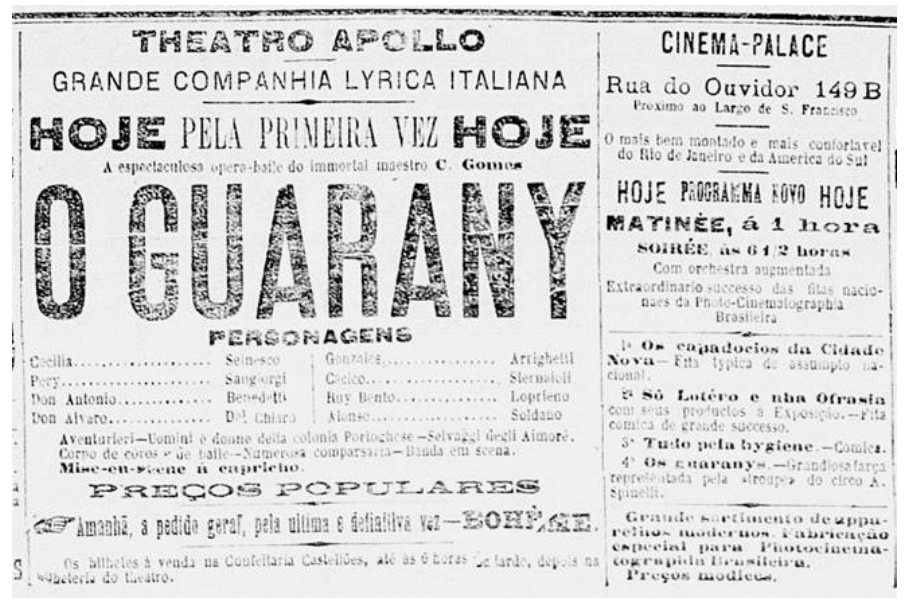

Fig. 3. Anúncio da exibição da ópera / Guarany no Teatro Apolo e da "grandiosa farsa" cinematográfica Os Guaranis, no CinemaPalace. Fonte: Teatro Apolo/ Cinema Palace, 1908, p. 8. Biblioteca Nacional Digital: <memoria.bn.br>

8 RAVIULI, 1909. A Viúva Alegre até mesmo migraria ao Circo Spinelli, amoldada numa versão para picadeiro. Cf. A VIÚVA ALEGRE... NO PICADEIRO, 1910. 
As personagens de ambos o romance indigenista de José de Alencar O Guarani e a ópera de Carlos Gomes I Guarany se misturavam no burilamento dos Peris cinematográficos. A fita de Benjamin de Oliveira lia os textos-base pela chave cômica, já que era denominada, como a pantomima que lhe deu origem, Os Guaranis. Mesmo assim, a ópera de Carlos Gomes acompanhava a versão da história para o picadeiro e, provavelmente, também a sua versão para o cinema, apresentada num tamanho mais enxuto na parte final de um programa do Cinema-Palace, para cuja soirée, segundo o anúncio, a orquestra seria aumentada ${ }^{9}$. Coincidentemente ou não, numa folha de 15 de setembro de 1908 ombreavam-se os anúncios da ópera de Gomes e da pantomima do Spinelli, conforme se pode observar pela figura 3, acima. Qual colcha de retalhos, o tecido social cosera uma obra noutra.

\section{Considerações finais}

Estas considerações finais não se querem, de modo algum, conclusões fechadas sobre o assunto tratado. Este trabalho é oriundo de um projeto de pós-doutorado que procura, por meio da pesquisa histórica, levantar as modalidades de usos dos sons no cinema silencioso, no Brasil (em especial no Rio de Janeiro) de fins do XIX ao início da década de 1920, no intuito de se estabelecerem as diferenças e semelhanças entre os contextos nacional e internacional. Em paralelo, tem-se por objetivo, a partir da bibliografia aqui arrolada, refletir-se teoricamente sobre o papel dos sons no cinema silencioso, sobretudo no que se diz respeito às especificidades nacionais de tal presença.

Este trabalho procura suprir uma lacuna nos estudos do cinema silencioso - lacuna para a qual, aliás, Souza (2014) aponta ao analisar o contexto paulistano de fins dos anos 20. A partir do levantamento da exibição cinematográfica do período, procuro sublinhar a relação estreita que o cinema estabeleceu, desde o princípio, com artefatos culturais que Ihe antecederam e lhe eram contemporâneos. Este trabalho tem um cunho transdisciplinar, filiando-se à perspectiva de Bernardet (2008), já apontada, e de Abel e Altman (2001, p. xiii), para os quais o cinema deste período, em especial o "cinema de atrações" (o qual compreendeu, grosso modo, até o início dos anos de 1910) constituía-se de uma hibridez que o atrelava incontornavelmente aos demais entretenimentos fruídos por aquela população que via a emergência da cultura de massa.

Ao percorrer as salas de exibições cinematográficas cariocas em paralelo ao âmbito cronístico, aos parques de diversões, aos espetáculos funambulescos, teatrais e às óperas, encenados no Brasil no período em que este estudo se atém, procuro assinalar - embora de maneira introdutória - que, a exemplo do contexto estrangeiro, também entre nós o cinema se beneficiou do constante resvalar entre as modalidades artísticas, para a construção de seus sentidos.

9 Segundo anúncio do Spinelli, a pantomima Os Guaranis era "ornada com 22 números de lindos trechos de música, extraídos da grande ópera O Guarani". Cf. CIRCO SPINELLI, 1908, p. 10. 
Danielle Crepaldi Carvalho é pós-doutoranda na ECA-USP (FAPESP). É doutora pela UNICAMP. É coorganizadora de edições anotadas de seletas de contos dedicados a João do Rio, a António de Alcântara Machado e aos escritores PréModernistas e Modernistas (todas pela Lazuli), e coautora da tradução e análise crítica do melodrama L'auberge des Adrets/A Estalagem dos Trampolineiros (publicada pela Penalux), marco da cena teatral francesa. Edita quinzenalmente o blog Filmes, filmes, filmes!

megchristie@gmail.com.

\section{Referências}

ABEL, R.; ALTMAN, R. (eds.). The Sounds of Early Cinema. Bloomington: Indiana University Press, 2001.

ALTMAN, R. The Musical Scene. In: Silent Film Sound. Maryland: Columbia University Press, 2004, p. 27-53.

ARAÚJO, V. de P. A bela época do cinema brasileiro. São Paulo: Editora Perspectiva, 1976.

BERNARDET, J.-C. Filmografia do cinema brasileiro (1900-1935). São Paulo: Gov. Estado SP, Secretaria da Cultura, Comissão de Cinema, 1979.

. Historiografia clássica do cinema brasileiro. 2. ed. São Paulo: Annablume, 2008.

CARVALHO, D. C. Luz e sombra no écran: realidade, cinema e rua nas crônicas cariocas de 1894 a 1922. Tese de doutorado. Campinas: IEL, UNICAMP, 2014.

CINEMA PALACE. Jornal do Brasil, Rio de Janeiro, 26 set. 1908, p. $10^{10}$.

CIRCO SPINELLI. Jornal do Brasil, Rio de Janeiro, 18 abr. 1908, p. 10.

COSTA, F. M. da. O som no cinema brasileiro. Rio de Janeiro: 7Letras/FAPERJ, 2008.

FLÁVIO (pseud. de PEDERNEIRAS, M.). Bilhetes à Cora. Fon-Fon, Rio de Janeiro, ano 3, n. 26, 26 de jun. 1909.

GAUMONT: Le Cinéma Premier (1907-1916). 2 Vols. DVDs.

GIANATI, M.; MANNONI, L. (org.) Alice Guy, Léon Gaumont et les débuts du film sonore. UK: John Libbey Publishing Ltd., 2012.

GIL. O Fonógrafo. Fon-Fon, Rio de Janeiro, 16 jan. 1909, ano III, n. 3.

GRAMOFONES e discos Victor. Gazeta de Notícias, 30 jan. 1911, p. 8.

GUNNING, T. Doing for the Eye What the Phonograph Does for the Ear. In: ABEL, R.; ALTMAN, R. (eds.). The Sounds of Early Cinema. op. cit., p. 13-31.

JOE (pseud. de BARRETO, P.). Cinematógrafo. Gazeta de Notícias, Rio de Janeiro, 29 set. 1907, p. 1.

10 Essas indicações de artigos sem nomes de autores devem-se ao fato de os textos não terem sido assinados à época, quando publicados na imprensa, ou de terem sido assinados originalmente por pseudônimos (no caso de as autorias empíricas terem sido descobertas, coloquei-as entre parênteses nas referências). 
O KINETOSCÓPIO. Gazeta de Notícias, Rio de Janeiro, 15 abr. 1894, p. 1.

KLENOTIC, J. The Sensational Acme of Realism: "Talker" Pictures as Early Cinema Sound Practice. In: The Sounds of Early Cinema. op. cit., p. 156-166.

MORETTIN, E. A representação da história no cinema brasileiro (1907-1949). Anais do Museu Paulista, N. Sér. V. 5, p. 249-271, jan.-dez. 1997.

Sonoridades do cinema dito silencioso: filmes cantantes, história e música. Significação, $\mathrm{n}$. 31, p. 149-162, 2009.

MORIN, E. O cinema ou o homem imaginário. Lisboa: Moraes Editores, 1970.

NOTAS DIVERSAS: Uma nova invenção de Edison. Jornal do Brasil, Rio de Janeiro, 19 jun. 1891, p. 1.

O. G. (pseud. de GUANABARINO, O.). Vida Social - Espetáculos: Filmes de arte. O País, Rio de Janeiro, 10 jan. 1909, p. 3.

OPINIÃO DA IMPRENSA. O Cinematógrafo, Rio de Janeiro, 2 dez. 1905, p. 1.

PALCOS E SALAS: Companhia Japonesa. A Notícia, Rio de Janeiro, 7-8 abr. 1903, p. 3.

PALCOS E SALÕES: Teatro Lírico. Jornal do Brasil, Rio de Janeiro, 28 nov. 1904, p. 2.

PEREIRA, C. E. A música no cinema silencioso no Brasil. Rio de Janeiro: Museu de Arte Moderna do Rio de Janeiro, 2014.

[PIMENTEL]. Binóculo. Gazeta de Notícias, Rio de Janeiro, 17 abr. 1908, p. 2.

PISANO, G. Sur la présence de la musique dans le cinéma dit muet. In : 1895 (Musique!) N. 38, octobre 2002.

RAVIULI. Viuvomania. Fon-Fon, Rio de Janeiro, ano III, n. 24, 12 jun. 1909.

REDONDO, G. O Fonógrafo. In: Cara alegre (paginas humorísticas). Porto: Livraria Chardron, de Lello \& Irmão, Editores, 1912.

SINCRONOSCÓPIO LíRICO. Fon-Fon, Rio de Janeiro, 26 set. 1908, ano II, n. 25.

SOUZA, C. R. de. Orquestras e vitrolas no acompanhamento do espetáculo cinematográfico silencioso brasileiro: o caso do cinema Triângulo, um saco de pancadas exemplar. Rebeca, ano 3, ed. 6, dez. 2014.

TEATRO APOLO/ CINEMA-PALACE. Gazeta de Notícias, Rio de Janeiro, 15 set. 1908, p. 8.

TEATRO LÍRICO. Gazeta de Notícias, Rio de Janeiro, 18 dez. 1904, p. 6.

TEATRO LÍRICO: Filmes de Arte. Gazeta de Notícias, Rio de Janeiro, 9 jan. 1909, p. 6.

TEATROS: LUCINDA. O Século. Rio de Janeiro, 9 nov. 1907, p. 3.

TEATROS E...: Parque Fluminense. Gazeta de Notícias, Rio de Janeiro, 13 abr. 1903, p. 2.

THOMASSEAU, J.-M. Mélodramatiques. Vincennes : Presses Universitaires de Vincennes; Saint-Denis, Université Paris 8, 2009.

A VIÚVA ALEGRE... No Picadeiro. Fon-Fon, Rio de Janeiro, ano II, n. 13, 26 mar. 1910.

Artigo recebido em maio e aprovado em setembro de 2016. 